\title{
Effects of feed restriction and prolactin-release inhibition at drying off on metabolism and mammary gland involution in cows
}

\author{
S. Ollier, ${ }^{*}$ X. Zhao, $†$ and P. Lacasse ${ }^{* 1}$ \\ *Dairy and Swine Research and Development Centre, Agriculture and Agri-Food Canada, Sherbrooke, Quebec, Canada J1M 0C8 \\ †Department of Animal Science, McGill University, Sainte-Anne-de-Bellevue, Quebec, Canada H9X 3V9
}

\begin{abstract}
A cow's risk of acquiring a new intramammary infection during the dry period increases with milk production at drying off and decreases as mammary gland involution progresses. A method commonly used to reduce milk production is a drastic reduction in feed supply in the days that precede drying off. Milk production can also be reduced by inhibiting the lactogenic signal driven by prolactin (PRL). This study aimed to compare the effects of these 2 drying-off procedures on metabolism, immunity, and mammary gland involution in cows. A total of 24 Holstein cows in late lactation were assigned to 1 of 3 treatments based on milk yield, somatic cell count, and parity. The cows were fed a lactation diet until drying off (control; $\mathrm{n}=8$ ), only dry hay during the last $5 \mathrm{~d}$ before drying off $(\mathrm{DH} ; \mathrm{n}=8)$, or the same lactation diet as the control cows but with twice-daily i.m. injections of $4 \mathrm{mg}$ of quinagolide, a specific inhibitor of PRL release, from $5 \mathrm{~d}$ before drying off until $13 \mathrm{~d}$ after (QN; $\mathrm{n}=8$ ). Quinagolide induced a decrease in PRL concentration in blood and in milk and mammary secretions on all the injection days. Interestingly, PRL was also depressed in the blood and milk of the hay-fed cows before drying off. Both the QN and DH treatments induced a decrease in milk production, which averaged 17.9 and $10.1 \mathrm{~kg} / \mathrm{d}$ for the QN and DH cows, respectively, at drying off in comparison with $24.8 \mathrm{~kg} / \mathrm{d}$ for the control cows. Both BSA concentration and $\mathrm{Na}^{+}$-to- $\mathrm{K}^{+}$ratio increased faster in the mammary secretions of both the DH and QN cows than in those of the control cows, whereas citrate-tolactoferrin ratio, another indicator of involution rate, decreased faster. The DH treatment decreased blood concentrations of glucose and most amino acids and increased blood concentrations of $\beta$-hydroxybutyrate and nonesterified fatty acids. Quinagolide increased blood glucose but did not affect the other metabolites. The serum harvested on $d-1$ from the hay-fed cows
\end{abstract}

Received January 7, 2014.

Accepted April 11, 2014.

${ }^{1}$ Corresponding author: Pierre.Lacasse@agr.gc.ca reduced peripheral blood mononuclear cell proliferation and IL-4 production, whereas the serum from the quinagolide-treated cows had no effect. In conclusion, this experiment shows that PRL-release inhibition could be a new alternative for reducing milk production before drying off and for hastening mammary gland involution without disturbing the metabolism of the cow. Key words: quinagolide, dry period, immunity, lymphocyte

\section{INTRODUCTION}

The lactation cycle of the dairy cow requires a dry period to renew mammary secretory cells. Although this period is important for optimal milk production in the subsequent lactation, the cow is highly susceptible to new IMI during the first $3 \mathrm{wk}$ of the dry period (Eberhart, 1986). With increasing milk production, drying off has become a challenging period for dairy cows. Although milk is no longer removed, the mammary gland temporarily continues to synthesize milk, which is an excellent medium for bacterial growth, and thus milk accumulation and leakage via the teats can occur, facilitating the entry of microorganisms into the mammary gland (Oliver and Sordillo, 1989). Consequently, the risk of acquiring a new infection during the dry period increases rapidly with the level of milk production (Rajala-Schultz et al., 2005). Once mammary gland involution is completed, within $30 \mathrm{~d}$ after cessation of milking, the mammary gland becomes much more resistant to new IMI because of a low fluid volume in the udder and a medium unfavorable for bacterial growth (Breau and Oliver, 1986). As it is now common to dry off cows that are still producing more than $25 \mathrm{~kg}$ of milk per day, it is important to develop strategies that reduce milk production before drying off and to hasten mammary gland involution.

A common drying-off practice among farmers involves a drastic short-term reduction in feed supply in the days that precede drying off. Although this method is effective for rapidly reducing milk yield (Bushe and Oliver, 1987), such a reduction in nutrient supply at drying off may lead to metabolic problems, especially among high-yielding cows. In previous studies, cows fed 
straw (Odensten et al., 2005) or hay (Bernier-Dodier et al., 2011) at drying off responded with an increase in plasma NEFA concentration comparable to the increase that can be observed in early lactation (Loiselle et al., 2009). In early lactation, metabolic stress is proportional to the negative nutrient balance, and the linkage between milk production and health disorders such as mastitis is well documented (Pryce et al., 1998). This high susceptibility is, in part, related to the fact that some immune functions, such as PMNL phagocytosis and oxidative burst activity, as well as blood lymphocyte responsiveness to mitogenic stimulation, are depressed (Kehrli et al., 1989a,b; Moreira da Silva et al., 1998). Recently, Ster et al. (2012) observed that immune functions, such as lymphocyte multiplication and cytokine release, were inhibited by serum obtained from periparturient cows and that this inhibition is directly related to NEFA concentration in the serum. It is therefore possible that part of the gain in disease resistance obtained by reducing milk production at drying off, by means of feed restriction, is loss due to an immunosuppression.

Milk production can also be reduced by decreasing the lactogenic signals driving milk production. Lacasse et al. (2011) recently showed that inhibiting prolactin (PRL) secretion with quinagolide gradually decreased milk production in cows at peak lactation. When applied to cows in late lactation, the same approach induced a sharp decrease in milk production within $24 \mathrm{~h}$, and some parameters suggested that involution had been hastened (Ollier et al., 2013). The effect of this strategy on the immune system and metabolism of cows has not yet been assessed. The present study aimed to compare the effects of PRL-release inhibition as a drying-off procedure with those of a drastic reduction in feed supply in the days preceding drying off on metabolism, immunity, and mammary gland involution in cows.

\section{MATERIALS AND METHODS}

\section{Animals and Experimental Design}

The experiment was conducted in accordance with the guidelines of the Canadian Council on Animal Care (1993). A total of 24 Holstein cows in late lactation (327 \pm 16 DIM at drying off) housed at Agriculture and Agri-Food Canada's Dairy and Swine Research and Development Centre (Sherbrooke, QC, Canada) were assigned to 1 of 3 treatments according to their milk yield, SCC, and parity. The cows were fed ad libitum (1) a late-lactation diet (containing dry hay, grass silage, corn silage, corn grain, soybean meal, and nonmineral and mineral supplements; Table 1) until
Table 1. Ingredient composition of diets

\begin{tabular}{lccc}
\hline $\begin{array}{l}\text { Ingredient composition } \\
\text { (\% of DM) }\end{array}$ & $\begin{array}{c}\text { Late lactation } \\
\text { diet }\end{array}$ & $\begin{array}{c}\text { Dry hay } \\
\text { diet }\end{array}$ & $\begin{array}{c}\text { Dry period } \\
\text { diet }\end{array}$ \\
\hline Dry hay & 7.3 & 100.0 & 74.9 \\
Grass silage & 28.8 & 0.0 & 0.0 \\
Corn silage & 28.6 & 0.0 & 11.3 \\
Corn grain & 21.3 & 0.0 & 0.0 \\
Soybean meal & 9.4 & 0.0 & 12.2 \\
Nonmineral supplement & 2.6 & 0.0 & 0.0 \\
Mineral supplement & 2.1 & 0.0 & 1.6 \\
\hline
\end{tabular}

drying off (control; $\mathrm{n}=8$ ); (2) only dry hay during the last $5 \mathrm{~d}$ before drying off $(\mathbf{D H} ; \mathrm{n}=8)$; or (3) the same late-lactation diet as the control cows but with twice-daily (at 0930 and $2130 \mathrm{~h}$ ) i.m. injections of $4 \mathrm{mg}$ of quinagolide (Ferring, Wallisellen, Switzerland) from $5 \mathrm{~d}$ before drying off until $13 \mathrm{~d}$ after $(\mathbf{Q N} ; \mathrm{n}=8)$. The control and DH cows received injections of the solvent (water). After drying off, the 24 cows were fed ad libitum a dry period diet containing (on a DM basis) $74.9 \%$ dry hay and $25.1 \%$ TMR (containing corn silage, soybean meal, and mineral supplement; Table 1). Feed intake was recorded daily throughout the experiment, and each cow's BW was determined at the start and at the end of the experiment.

\section{Milk and Mammary Secretion Collection}

The cows were milked twice daily, at 0730 and $2030 \mathrm{~h}$, and milk yield was recorded at each milking during the last $2 \mathrm{wk}$ before drying off. Milk samples $(60 \mathrm{~mL})$ were manually collected from each quarter just before the morning milking on the last $7 \mathrm{~d}$ before drying off (d -7 to -1 ) and then mixed together for each cow and each day. After the last milking, each quarter was treated with dry cow therapy containing penicillin and novobiocin (Novodry Plus; Pfizer Canada Inc., Kirkland, QC, Canada). Mammary secretions (60 mL) were manually collected from 1 quarter at $0730 \mathrm{~h}$ on $\mathrm{d} 1$, $3,5,7,10$, and 14 after the last milking. The sampled quarter was alternated at each sampling and the teat was dipped into a teat protection sealant containing $0.1 \%$ triclosan (Uddergold Dry; Ecolab Inc., St. Paul, $\mathrm{MN})$ after the sample was taken. Quarters with high SCC $(>250$ cells $/ \mu \mathrm{L})$ or detectable pathogens before the start of the experiment were excluded from sampling. The samples were used to measure SCC and were then skimmed by centrifugation $\left(1,900 \times g, 4^{\circ} \mathrm{C}, 15 \mathrm{~min}\right)$ and stored at $-20^{\circ} \mathrm{C}$ until determination of PRL, BSA, lactoferrin, citrate, $\mathrm{Na}^{+}$, and $\mathrm{K}^{+}$concentrations, as well as gelatinase activity.

\section{Blood Collection}

Caudal blood samples were taken just before collection of milk and mammary secretions on $\mathrm{d}-7$ to 
-1 , and on $\mathrm{d} 1,3,5,7,10$, and 14 in Vacutainer collection tubes without additives and in EDTA-coated Vacutainer tubes (BD, Mississauga, ON, Canada). On $\mathrm{d}-7$ (before the start of treatments) and -1 (before drying off), several blood samples were collected in tubes without additives before, during, and after the morning milking $(-20,-10,0,3,5,7,10,15,20,25$, 30,40 , and 60 min relative to the start of milking) from a Silastic catheter (i.d. $1.02 \mathrm{~mm}$, o.d. $2.16 \mathrm{~mm}$; Dow Corning Corp., Midland, MI) inserted into the jugular vein. All the blood tubes without additives were left at room temperature for approximately $2 \mathrm{~h}$ to allow clotting before centrifugation $\left(1,900 \times g, 4^{\circ} \mathrm{C}, 15 \mathrm{~min}\right)$. Then, the serum was stored at $-20^{\circ} \mathrm{C}$ until determination of PRL concentration. The blood tubes containing EDTA were placed on ice immediately after collection and centrifuged $\left(1,900 \times g, 4^{\circ} \mathrm{C}, 15 \mathrm{~min}\right)$ within $30 \mathrm{~min}$. Then, the plasma was stored at $-20^{\circ} \mathrm{C}$ until determination of glucose, NEFA, and BHBA concentrations.

Jugular blood samples $(250 \mathrm{~mL})$ were taken on d -6 , -1 , and 2 using Vacutainer collection tubes without additives. The tubes were left at room temperature for approximately $2 \mathrm{~h}$ to allow clotting before centrifugation $\left(1,900 \times g, 4^{\circ} \mathrm{C}, 15 \mathrm{~min}\right)$. Then, the serum was stored at $-20^{\circ} \mathrm{C}$ until peripheral blood mononuclear cell (PBMC) proliferation assays were performed. Plasma samples were also taken on $\mathrm{d}-6,-1$, and 2 using Vacutainer sodium heparin collection tubes. The blood tubes were placed on ice immediately after collection and centrifuged $\left(1,900 \times g, 4^{\circ} \mathrm{C}, 15 \mathrm{~min}\right)$ within $30 \mathrm{~min}$. Then, $1 \mathrm{~g}$ of plasma was immediately added to $0.2 \mathrm{~g}$ of an internal standard, consisting of a mixture of labeled AA (Doepel and Lapierre, 2010), and stored at $-80^{\circ} \mathrm{C}$ until AA analysis.

\section{PRL Concentration}

The concentration of PRL in serum and in skim milk and mammary secretions was measured by RIA as described by Bernier-Dodier et al. (2011). Bovine PRL, rabbit antiserum specific for bovine PRL, and goat anti-rabbit gamma globulin were purchased from the National Hormone and Peptide Program (HarborUCLA Medical Center, Torrance, CA). The intra- and interassay coefficients of variation were 3.8 and $5.8 \%$, respectively, for serum, and 6.6 and $6.4 \%$, respectively, for milk and mammary secretions.

\section{SCC in Milk and Mammary Secretions}

Somatic cell count was determined from fresh whole milk and mammary secretion samples using an automatic cell counter (DeLaval International AB, Tumba, Sweden). Samples of mammary secretions were diluted with commercial, skimmed, microfiltered milk until the SCC obtained was between 100 and 200 cells/ $\mu \mathrm{L}$.

\section{BSA Concentration in Milk and Mammary Secretions}

The concentration of BSA in milk and mammary secretion samples was evaluated by a colorimetric assay, as previously described (Ollier et al., 2013). The intra- and interassay coefficients of variation were 1.2 and $7.0 \%$, respectively.

\section{Lactoferrin and Citrate Concentrations in Milk and Mammary Secretions}

The concentration of lactoferrin in skim milk and mammary secretions was measured by ELISA using a commercial bovine lactoferrin ELISA quantitation set (Bethyl Laboratories Inc., Montgomery, TX). The intra- and interassay coefficients of variation were 5.7 and $9.9 \%$, respectively. Citrate concentration was measured by enzymatic analysis (Mollering, 1989) using a commercial kit (Megazyme International Ireland, Bray, Ireland) from deproteinized, skimmed samples, as previously described (Ollier et al., 2013). The intra- and interassay coefficients of variation were 1.4 and $2.2 \%$, respectively. The citrate-to-lactoferrin molar ratio was calculated for each sample using the following equation: (citrate concentration/citrate molecular weight)/(lactoferrin concentration/lactoferrin molecular weight); the molecular weights of citrate and lactoferrin were 192.1 and $78,056 \mathrm{~g} / \mathrm{mol}$, respectively.

\section{$\mathrm{Na}^{+}$and $\mathrm{K}^{+}$Concentrations in Milk and Mammary Secretions}

The concentrations of $\mathrm{Na}^{+}$and $\mathrm{K}^{+}$in skim milk and mammary secretions were determined by flame atomic emission spectrometry using an atomic absorption spectrophotometer (AAnalyst 300 Spectrometer, Perkin Elmer Instruments, Woodbridge, ON, Canada), as previously described (Ollier et al., 2013). The intra- and interassay coefficients of variation were 0.4 and $1.0 \%$, respectively, for $\mathrm{Na}^{+}$, and 1.1 and $1.5 \%$, respectively, for $\mathrm{K}^{+}$. The $\mathrm{Na}^{+}$-to- $\mathrm{K}^{+}$molar ratio was calculated for each sample using the following equation: $\left(\mathrm{Na}^{+}\right.$concentration $/ \mathrm{Na}^{+}$molecular weight $) /\left(\mathrm{K}^{+}\right.$concentration $/ \mathrm{K}^{+}$ molecular weight); the molecular weights of $\mathrm{Na}^{+}$and $\mathrm{K}^{+}$were 23.0 and $39.1 \mathrm{~g} / \mathrm{mol}$, respectively.

\section{Gelatinase Activity in Milk and Mammary Secretions}

Gelatin zymography was performed as previously described (Tremblay et al., 2009), with the exception that $2 \mu \mathrm{L}$ of skim milk sampled on $\mathrm{d}-7$ to $-1,1 \mu \mathrm{L}$ 
of skimmed mammary secretions sampled on d 1,3 , 5 , and 7 , or $0.5 \mu \mathrm{L}$ of secretions sampled on d 10 and 14 were separated on $10 \%$ polyacrylamide gels containing gelatin at $2 \mathrm{mg} / \mathrm{mL}$. The gels were incubated in developing buffer $(50 \mathrm{~m} M$ Tris base, $200 \mathrm{mM} \mathrm{NaCl}$, $5 \mathrm{mM} \mathrm{CaCl} 2$, and $0.02 \%$ Brij 35 detergent) at $37^{\circ} \mathrm{C}$ for $22 \mathrm{~h}$ before staining and destaining. Integrated density values of bands from samples from $\mathrm{d}-7$ to -1 and from d 10 to 14 were divided by 2 and multiplied by 2 , respectively.

\section{Metabolite Concentrations in Plasma}

Plasma glucose concentration was determined as previously described (Loiselle et al., 2009) using a glucose assay kit (Roche Diagnostics, Laval, QC, Canada) employing a modification of the glucose oxidase and peroxidase method described by Trinder (1969). The intra- and interassay coefficients of variation were 1.0 and $2.2 \%$, respectively. Plasma NEFA concentration was determined by an enzymatic colorimetric method using NEFA-HR(2) reagents (Wako Diagnostics, Richmond, VA). Briefly, $200 \mu \mathrm{L}$ of reagent A was added to $10 \mu \mathrm{L}$ of the plasma sample in a 96-well microplate, which was then incubated at $37^{\circ} \mathrm{C}$ for $5 \mathrm{~min}$. Next, $100 \mu \mathrm{L}$ of reagent $\mathrm{B}$ was added, and the microplate was incubated at $37^{\circ} \mathrm{C}$ for an additional $5 \mathrm{~min}$. The microplate was kept at room temperature for $15 \mathrm{~min}$, and absorbance was read at $550 \mathrm{~nm}$ using a SpectraMax 250 microplate reader (Molecular Devices, Sunnydale, CA). The intraand interassay coefficients of variation were 3.3 and $2.8 \%$, respectively. Plasma BHBA concentration was determined by an enzymatic colorimetric method using a BHBA reagent set (Pointe Scientific Inc., Canton, MI). Briefly, $300 \mu \mathrm{L}$ of the working reagent was added to $8 \mu \mathrm{L}$ of the plasma sample in a 96-well microplate, which was then incubated at $37^{\circ} \mathrm{C}$ for $5 \mathrm{~min}$. Absorbance was read at $550 \mathrm{~nm}$ using a SpectraMax 250 microplate reader (Molecular Devices). The intra- and interassay coefficients of variation were 1.5 and $2.6 \%$, respectively.

\section{AA Concentrations in Plasma}

Plasma AA concentrations were determined by the isotope dilution method of Calder et al. (1999). Briefly, plasma samples were deproteinized with sulfosalicylic acid $(38 \%)$ and centrifuged at 21,100 $\times g$ for $15 \mathrm{~min}$ at $4^{\circ} \mathrm{C}$. The supernatants were eluted through a PolyPrep chromatography column (Resin 100-200 mesh H; Bio-Rad Laboratories, Mississauga, ON, Canada) and derivatized with $N$-tert-butyldimethylsilyl- $N$ methyltrifluoroacetamide and dimethylformamide (Sigma-Aldrich, Oakville, ON, Canada) in a 1:1 ratio.
Measurements of the isotopic enrichment in processed samples were performed using a GC-MS system (Model GC6890-MS5973; Hewlett Packard Co., Wilmington, $\mathrm{DE})$.

\section{PBMC Proliferation Assay and Production of IL-4}

Peripheral blood mononuclear cells were isolated from the jugular blood of 2 healthy cows in midlactation; the blood had been collected in EDTA-coated Vacutainer tubes (BD). The blood was centrifuged at $1,200 \times g$ for 15 min at $18^{\circ} \mathrm{C}$, and the buffy coat diluted in RPMI 1640 (Wisent Inc., St-Bruno, QC, Canada) was layered on Ficoll-Paque Plus (GE Healthcare, Baie-d'Urfé, QC, Canada) and centrifuged at $850 \times g$ for $35 \mathrm{~min}$ at $18^{\circ} \mathrm{C}$. The PBMC layer was washed with RPMI 1640 and centrifuged at $500 \times g$ for $8 \mathrm{~min}$ at $18^{\circ} \mathrm{C}$. The pellet was layered on sterile $20 \%$ sucrose and centrifuged at $500 \times g$ for $8 \mathrm{~min}$ at $18^{\circ} \mathrm{C}$. The pellet was then washed with RPMI 1640 and centrifuged at $200 \times g$ for $8 \mathrm{~min}$ at $18^{\circ} \mathrm{C}$. Red blood cells were lysed with sterile Tris- $\mathrm{NH}_{4} \mathrm{Cl}$ and, after centrifugation at $200 \times g$ for $8 \mathrm{~min}$ at $18^{\circ} \mathrm{C}$, the pellet was washed with RPMI 1640 and centrifuged at $100 \times g$ for $8 \mathrm{~min}$ at $18^{\circ} \mathrm{C}$. The PBMC were suspended in RPMI 1640, and live cell concentration was determined using a Countess automated cell counter (Invitrogen, Burlington, ON, Canada). Then, the PBMC were labeled with $1 \mu M$ carboxyfluorescein diacetate, succinimidyl ester using a Vybrant CFDA SE cell tracer kit (Molecular Probes, Burlington, ON, Canada). To assess the effect of the serum from treated cows on PBMC proliferation, labeled PBMC suspended in RPMI 1640 supplemented with antimicrobial agents and L-Gln (Wisent Inc.), and with $5 \%$ decomplemented (by heating for $30 \mathrm{~min}$ at $56^{\circ} \mathrm{C}$ ) serum sampled on $\mathrm{d}-6,-1$, or 2 from each cow were incubated in a 12 -well plate $\left(3 \times 10^{6}\right.$ cells per well $)$ at $37^{\circ} \mathrm{C}$ for $3.5 \mathrm{~d}$. For each serum tested, the PBMC of 2 wells were incubated with concanavalin A (SigmaAldrich) at $1 \mu \mathrm{g} / \mathrm{mL}$, and the PBMC of 1 well were incubated without the mitogen as a negative control. After $3.5 \mathrm{~d}$, the cells were fixed using $4 \%$ formaldehyde, and proliferation was analyzed using a FACSCanto II flow cytometer (BD Biosciences, Mississauga, ON, Canada). This assay was performed 3 times for each serum and for the 2 cows from which the PBMC had been taken. The percentage of proliferation was corrected by the percentage of proliferation obtained from a control-positive serum included in each assay. This control-positive serum was obtained by mixing serum from 4 healthy cows in midlactation.

With a view to assessing IL- 4 production, $1 \mathrm{~mL}$ of cell culture supernatant from each well was collected after $24 \mathrm{~h}$ of incubation and stored at $-20^{\circ} \mathrm{C}$. The concentra- 
tion of IL-4 was measured using a commercial bovine IL-4 ELISA kit (Thermo Scientific, Rockford, IL). The intra- and interassay coefficients of variation were 7.6 and $16.1 \%$, respectively. The concentration of IL-4 was corrected by the concentration of IL- 4 obtained from the cell culture supernatant with the control-positive serum.

\section{Statistical Analysis}

Data were analyzed separately for the pretreatment period $(\mathrm{d}<-5)$, the pre-drying off treatment period (d -5 to -1 ), and the post-drying off treatment period (d 1 to 14) by ANOVA using the MIXED procedure of the SAS software package (SAS Institute Inc., Cary, NC). Time was used as a repeated effect and cow (treatment) was used as the subject. The amount of PRL released into the blood during milking was calculated by determining the area under the curve between 0 and 40 min relative to the start of milking, and basal PRL concentration was calculated by averaging the concentrations obtained between -20 and 0 min. Somatic cell count, BSA concentration, citrate-to-lactoferrin ratio, $\mathrm{Na}^{+}$-to- $\mathrm{K}^{+}$ratio, and gelatinase activities were $\log _{10^{-}}$ transformed before analysis. The corrected percentage of PBMC proliferation and the corrected IL-4 concentration on $\mathrm{d}-6$ were used as a covariate for PBMC proliferation and IL-4 production analyses, respectively, on $\mathrm{d}-1$ and 2. Orthogonal contrasts were used to compare least squares means between the QN and control groups and between the DH and control groups. For PBMC proliferation and IL-4 production, the least squares means of the $\mathrm{DH}$ cows were compared with those of the QN and control cows. The least squares means of the QN and DH groups were compared using the Tukey-Kramer adjustment. The correlations between the PRL concentration in blood and that in milk, and between the corrected PBMC proliferation, the corrected IL- 4 concentration, and the blood concentration of metabolites were evaluated using the CORR procedure of SAS. Differences were considered statistically significant when $P<0.05$.

\section{RESULTS}

\section{DMI, Milk Production, and PRL Concentration}

During the pretreatment period, DMI was similar for the 3 groups of animals (Figure 1). After the start of the treatments and before drying off (pre-drying off treatment period, $\mathrm{d}-5$ to -1 ), the quinagolide-treated cows ate less than the control cows $(-24 \%, P<0.001)$. As expected, DMI was lower in the DH cows than in the control cows $(-65 \%, P<0.001)$ and $\mathrm{QN}$ cows $(-54 \%$,

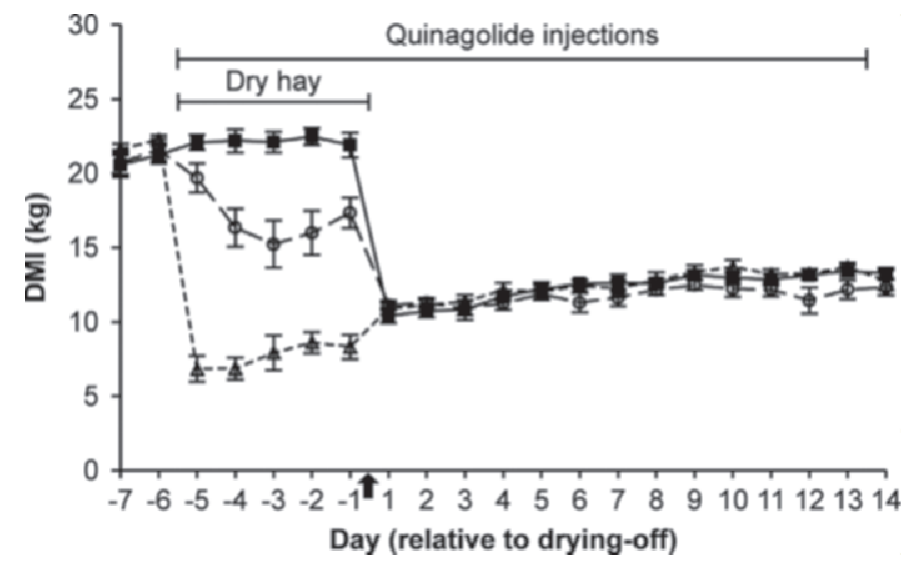

Figure 1. Dry matter intake of cows injected twice daily with $4 \mathrm{mg}$ of quinagolide from $5 \mathrm{~d}$ before drying off until $13 \mathrm{~d}$ after $(\mathrm{O}$, long-dashed line; $\mathrm{n}=8$ ), cows fed only dry hay for the last $5 \mathrm{~d}$ before drying off $(\Delta$, short-dashed line; $\mathrm{n}=8)$, and control cows $(\boldsymbol{\square}$, solid line; $\mathrm{n}=8$ ). Drying off is indicated by an arrow. Data are presented as $\mathrm{LSM} \pm \mathrm{SEM}$.

$P<0.001)$ during the pre-drying off treatment period. When the cows were fed the same dry period diet, DMI was again similar for the 3 groups (d 1 to 14 ). At the start and end of the experiment, BW was similar for the 3 groups of cows (data not shown).

Milk production was similar for the 3 groups of animals before the start of the experiment $(25.3 \pm$ $1.1 \mathrm{~kg} / \mathrm{d}$ on average between $\mathrm{d}-10$ and -6 ; Figure 2). From the first injection day, quinagolide reduced $(P<$ 0.001) milk production, which was $28 \%$ lower in the $\mathrm{QN}$ cows than in the control cows just before drying off. The hay treatment gradually reduced milk production $(P<0.001)$, which averaged $41 \%$ of that of the control treatment just before drying off. Milk production was lower in the $\mathrm{DH}$ cows than in the QN cows on $\mathrm{d}-2(P$ $=0.043)$ and $\mathrm{d}-1(P=0.007)$.

Basal blood PRL concentration was similar for the 3 groups of animals during the pretreatment period (Figure 3A). On all the injection days, PRL concentration in the quinagolide-treated cows was lower than that in the control cows $(P<0.001)$ and $\mathrm{DH}$ cows $(P=0.004$ between $\mathrm{d}-5$ and -1 , and $P<0.001$ between $\mathrm{d} 1$ and 14), and averaged $10 \%$ of that of the control cows during the treatment period ( $\mathrm{d}-5$ to 14$)$. Interestingly, PRL in the $\mathrm{DH}$ cows was also depressed $(P=0.037)$ and averaged $67 \%$ of that in the control cows before drying off ( $\mathrm{d}-5$ to -1$)$. After drying off, however, basal PRL concentration was again similar for the DH and control cows. The concentration of PRL was also determined in milk and mammary secretions and was similar for the 3 groups of animals during the pretreatment period (Figure 3B). As in blood, PRL concentration in milk and mammary secretions was lower in the quinagolide-treated cows than in the con- 


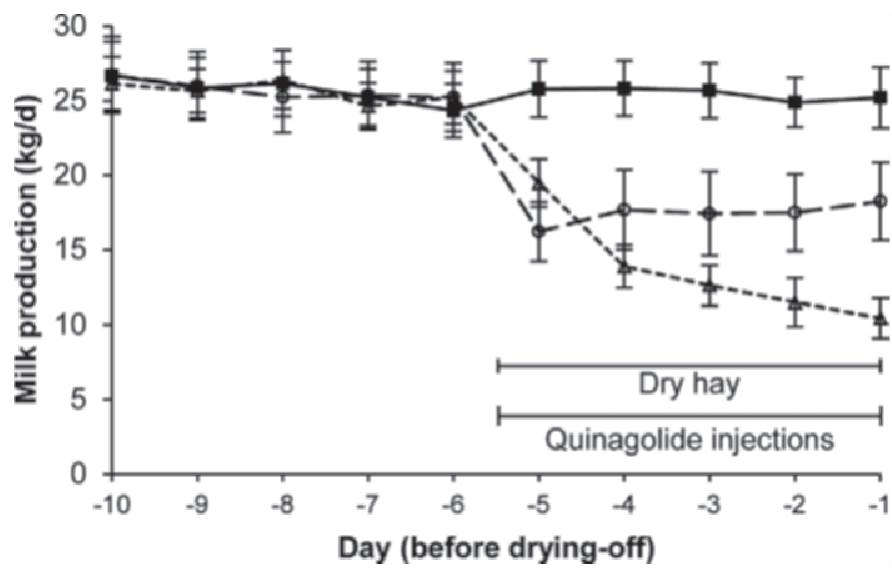

Figure 2. Milk production during the last $10 \mathrm{~d}$ of lactation in cows injected twice daily with $4 \mathrm{mg}$ of quinagolide from $5 \mathrm{~d}$ before drying off until 13 d after $(\bigcirc$, long-dashed line; $\mathrm{n}=8)$, cows fed only dry hay for the last $5 \mathrm{~d}$ before drying off $(\Delta$, short-dashed line; $\mathrm{n}=8)$, and control cows $(\mathbf{\square}$, solid line; $\mathrm{n}=8)$. Data are presented as LSM \pm SEM.

trol cows $(P<0.001$ between $\mathrm{d}-5$ and 14$)$ and $\mathrm{DH}$ cows $(P<0.001$ between $\mathrm{d}-5$ and -1 , and $P=0.001$ between $\mathrm{d} 1$ and 14). However, PRL concentration in milk and mammary secretions was similar for the $\mathrm{DH}$ and control groups before and after drying off $(\mathrm{d}-5$ to 14), and increased $(P<0.001)$ during the first $2 \mathrm{wk}$ of the dry period in both groups. The total amount of PRL secreted in milk was also similar for the 3 groups of animals during the pretreatment period and averaged $205 \pm 22,230 \pm 31$, and $201 \pm 13 \mu \mathrm{g} / \mathrm{d}$ in the QN, DH, and control cows, respectively. Quinagolide injections decreased PRL secretion $(68 \pm 10 \mu \mathrm{g} / \mathrm{d}$ on average between $\mathrm{d}-5$ and -1 ) in comparison with the control treatment $(197 \pm 9 \mu \mathrm{g} / \mathrm{d}, P<0.001)$ and $\mathrm{DH}$ treatment $(110 \pm 17 \mu \mathrm{g} / \mathrm{d}, P=0.021)$. The secretion of PRL in milk was also depressed $(P<0.001)$ in the $\mathrm{DH}$ cows in comparison with the control cows between $\mathrm{d}-5$ and -1 . A correlation between blood and milk PRL concentrations was found before drying off $(\mathrm{r}=$ $0.52, P<0.001$ ), as was a correlation between blood PRL concentration and PRL secretion in milk $(\mathrm{r}=$ 0.51, $P<0.001)$.

Milking-induced PRL release in blood was measured on $\mathrm{d}-7$ (before treatments) and -1 ( $5 \mathrm{~d}$ after the start of treatments). During the $\mathrm{d}-7$ milking, the total amount of PRL released was similar for the 3 groups of animals $(829 \pm 95,816 \pm 116$, and $775 \pm 136 \mathrm{ng} \cdot \mathrm{min} /$ $\mathrm{mL}$ in the $\mathrm{QN}, \mathrm{DH}$, and control cows, respectively). Conversely, during the $\mathrm{d}-1$ milking, quinagolide treatment decreased the total amount of PRL released $(118 \pm 27 \mathrm{ng} \cdot \mathrm{min} / \mathrm{mL})$ in comparison with the control treatment $(895 \pm 173 \mathrm{ng} \cdot \mathrm{min} / \mathrm{mL}, P=0.001)$ and $\mathrm{DH}$ treatment $(724 \pm 170 \mathrm{ng} \cdot \mathrm{min} / \mathrm{mL}, P=0.019)$; however, no difference was observed between the $\mathrm{DH}$ and control cows. Before the $\mathrm{d}-7$ milking, basal PRL concentration was similar for the 3 groups and averaged $15.4 \pm$ $2.4,14.8 \pm 1.5$, and $15.9 \pm 2.6 \mathrm{ng} / \mathrm{mL}$ in the QN, DH, and control cows, respectively. Before the $\mathrm{d}-1$ milking, basal PRL concentration was lower in the QN cows (2.4 $\pm 0.7 \mathrm{ng} / \mathrm{mL})$ than in the control cows $(14.9 \pm 1.4 \mathrm{ng} /$ $\mathrm{mL}, P<0.001)$ and $\mathrm{DH}$ cows $(10.5 \pm 2.0 \mathrm{ng} / \mathrm{mL}, P=$ $0.002)$, and was also lower in the DH cows than in the control cows $(P=0.041)$.

\section{Mammary Gland Involution Markers}

Somatic cell count, BSA concentration, citrate-tolactoferrin molar ratio, and $\mathrm{Na}^{+}$-to- $\mathrm{K}^{+}$molar ratio in milk and mammary secretions are presented in Figure 4. No differences were observed between the 3 groups of animals for all these parameters during the pretreatment period (on $\mathrm{d}-7$ and -6 ). During the pre-drying off treatment period, SCC increased in the milk of the $\mathrm{QN}$ and DH cows, was greater in the milk of those cows
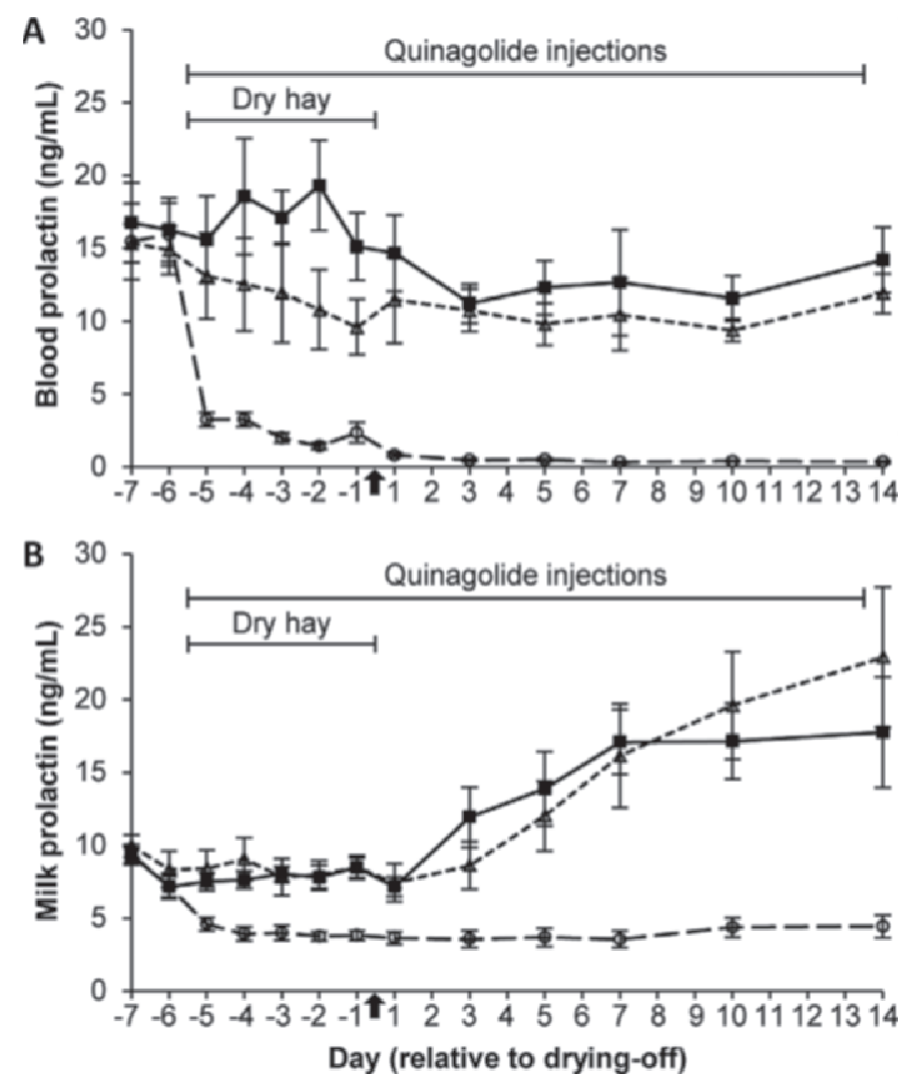

Figure 3. Basal concentration of prolactin in blood (A) and in milk and mammary secretions (B) of cows injected twice daily with $4 \mathrm{mg}$ of quinagolide from $5 \mathrm{~d}$ before drying off until $13 \mathrm{~d}$ after $(\mathrm{O}$, long-dashed line; $\mathrm{n}=8)$, cows fed only dry hay for the last $5 \mathrm{~d}$ before drying off $(\Delta$, short-dashed line; $\mathrm{n}=8)$, and control cows $(\boldsymbol{\square}$, solid line; $\mathrm{n}=8)$. Drying off is indicated by an arrow. Data are presented as $\mathrm{LSM} \pm \mathrm{SEM}$. 
than in that of the control cows $(P=0.026$ and $P=$ 0.001 , respectively; Figure 4A), and was similar for the $\mathrm{QN}$ and DH cows. After drying off, SCC increased in the mammary secretions of the 3 groups of animals ( $P$ $<0.001$ between $\mathrm{d} 1$ and 14) and tended to be greater $(P=0.057)$ in the QN cows than in the control cows.

Before drying off ( $\mathrm{d}-5$ to -1$)$, BSA concentration was greater in the milk of the QN cows $(P=0.035)$ and DH cows $(P<0.001)$ than in that of the control cows, and was also greater in the milk of the $\mathrm{DH}$ cows than in that of the QN cows $(P=0.001$; Figure $4 \mathrm{~B})$. During the first 2 wk of the dry period, BSA concentration increased $(P<0.001)$ regardless of the treatment, but was greater in the mammary secretions of the QN cows $(P=0.015)$ and $\mathrm{DH}$ cows $(P=0.013)$ than in that of the control cows. However, BSA concentration was similar for the QN and DH groups after drying off.

Before drying off, citrate concentration increased in the milk of the DH cows in comparison with the QN and control cows $(P=0.029$ and $P=0.004$, respectively; Supplemental Figure S1A; http://dx.doi.org/10.3168/ jds.2014-7914/). In the 3 groups of animals, citrate concentration decreased $(P=0.002)$ during the first 2 wk of the dry period, but was lower in the mammary secretions of the QN cows $(P=0.002)$ and DH cows $(P$ $<0.001)$ than in those of the control cows. Citrate concentration was similar for the QN and DH groups after drying off. Before drying off, lactoferrin concentration was greater in the milk of the QN cows $(P=0.011)$ and DH cows $(P=0.003)$ than in that of the control cows (Supplemental Figure S1B). Lactoferrin concentration increased $(P<0.001)$ during the first 2 wk of the dry period regardless of the treatment, but was greater in the mammary secretions of the QN cows $(P=0.005)$ and DH cows $(P=0.035)$ than in those of the control cows. Lactoferrin concentration was similar for the QN and DH groups before and after drying off. Before drying off, a treatment $\times$ time interaction $(P<0.001)$ was observed for citrate-to-lactoferrin ratio, which was lower in the QN cows from $\mathrm{d}-3$ to $-1(P<0.05)$ and the $\mathrm{DH}$ cows on $\mathrm{d}-1(P=0.033)$ than in the control cows (Figure $4 \mathrm{C})$. This ratio decreased $(P<0.001)$ during the first 2 wk of the dry period in the 3 groups of animals, but was lower $(P<0.001)$ in the mammary secretions of the QN and $\mathrm{DH}$ cows than in those of the control cows. Citrate-to-lactoferrin ratio was similar for the QN and DH groups after drying off.

Before drying off, $\mathrm{Na}^{+}$concentration was greater in the milk of the DH cows than in that of the control cows $(P=0.012$; data not shown). In the 3 groups of animals, $\mathrm{Na}^{+}$concentration increased $(P<0.001)$ during the first $2 \mathrm{wk}$ of the dry period but was greater in the mammary secretions of the QN cows $(P=0.011)$ and DH cows $(P<0.001)$ than in those of the control cows. Before and after drying off, $\mathrm{Na}^{+}$concentration was similar for the QN and DH cows. Before drying off, $\mathrm{K}^{+}$concentration decreased in the milk of the $\mathrm{DH}$ cows in comparison with the QN and control cows $(P=$ 0.043 and $P=0.003$, respectively; data not shown). Regardless of the treatment, $\mathrm{K}^{+}$concentration decreased $(P<0.001)$ during the first 2 wk of the dry period, but was lower in the mammary secretions of the QN cows $(P=0.017)$ and DH cows $(P<0.001)$ than in those of the control cows. After drying off, $\mathrm{K}^{+}$concentration was similar for the QN and DH cows. Before drying off, the milk $\mathrm{Na}^{+}$-to- $\mathrm{K}^{+}$ratio of the $\mathrm{DH}$ cows was greater than that of the control cows $(P=0.008)$ and tended to be greater than that of the QN cows $(P=0.078$; Figure $4 \mathrm{D})$. This ratio increased $(P<0.001)$ during the first 2 wk of the dry period in the 3 groups of animals, but was greater in the mammary secretions of the QN cows $(P=0.012)$ and DH cows $(P=0.001)$ than in those of the control cows. After drying off, $\mathrm{Na}^{+}$-to- $\mathrm{K}^{+}$ratio was similar for the QN and DH cows.

Gelatin zymography was used to measure matrix metalloproteinase (MMP) activities in milk and mammary secretions. Two main gelatinases, MMP-2 and MMP-9, were identified according to their apparent molecular weights (Snoek-van Beurden and Von den Hoff, 2005). No differences in MMP-9 activity between the 3 groups of animals were observed during the pretreatment and treatment periods, before and after drying off, although it increased during the first $2 \mathrm{wk}$ of the dry period $(P<0.001$; data not shown). During the pretreatment period, milk MMP-2 activity in the QN cows was similar to that in the $\mathrm{DH}$ and control cows, but was slightly greater in the $\mathrm{DH}$ cows than in the control cows $(P=0.038$; Figure $4 \mathrm{E})$. During the predrying-off treatment period, MMP-2 activity in the milk of the DH cows increased and was greater than that in the milk of the QN and control cows $(P$ $=0.002$ and $P<0.001$, respectively). Milk MMP-2 activity was also greater $(P<0.001)$ in the $\mathrm{QN}$ cows than in the control cows between $\mathrm{d}-5$ and -1 . After drying-off, MMP-2 activity increased $(P<0.001)$ in mammary secretions regardless of the treatment, and a treatment $\times$ time interaction $(P=0.004)$ was found. On d 1, MMP-2 activity was greater in the mammary secretions of the $\mathrm{DH}$ cows than in those of the QN and control cows $(P=0.023$ and $P<0.001$, respectively).

\section{Metabolic Markers}

The effects of the treatments on plasma glucose, NEFA, and BHBA concentrations are presented in Figure 5. No differences were observed between the 3 groups of animals for all 3 of these parameters during the pretreatment period (on $\mathrm{d}-7$ and -6 ). As 

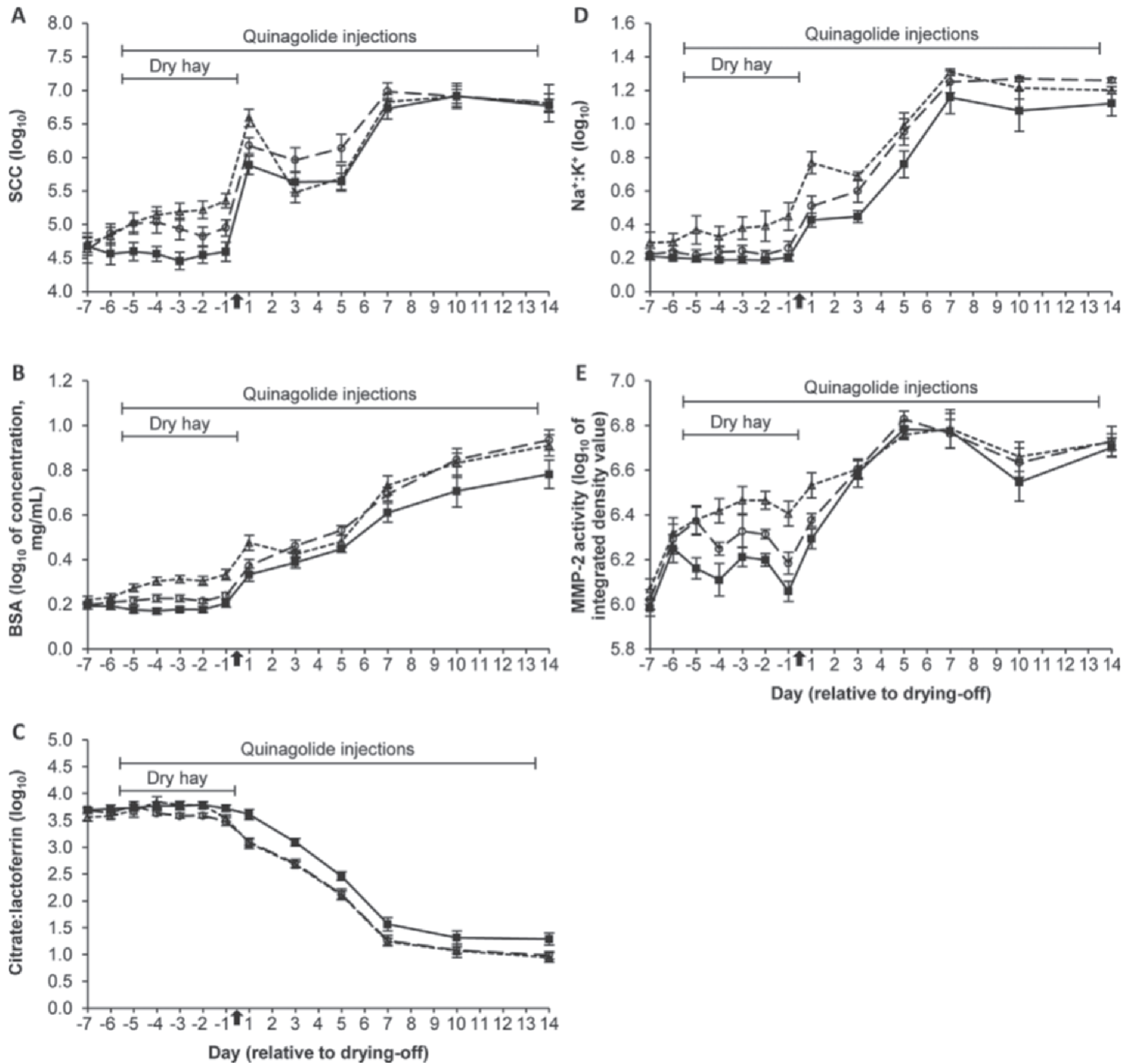

Figure 4. Somatic cell count (A), BSA concentration (B), citrate-to-lactoferrin molar ratio (C), $\mathrm{Na}^{+}$-to- $\mathrm{K}^{+}$molar ratio (D), and matrix metalloproteinase-2 (MMP-2) activity (E) in milk and mammary secretions of cows injected twice daily with 4 mg of quinagolide from $5 \mathrm{~d}$ before drying off until 13 d after $(O$, long-dashed line; $\mathrm{n}=8)$, cows fed only dry hay for the last $5 \mathrm{~d}$ before drying off $(\Delta$, short-dashed line; $\mathrm{n}=8)$, and control cows $(\boldsymbol{\square}$, solid line; $\mathrm{n}=8)$. Drying off is indicated by an arrow. Data are presented as LSM \pm SEM of $\log _{10}$-transformed values. Prior to $\log _{10}$ calculation, +2 and +1 were added to BSA concentrations and $\mathrm{Na}^{+}$-to- $\mathrm{K}^{+}$molar ratios, respectively.

expected, plasma glucose concentration was lower in the DH cows than in the QN and control cows during the pre-drying off treatment period $(P<0.001$; Figure $5 \mathrm{~A})$. After drying off, plasma glucose concentration in the DH cows increased and became greater than that in the control cows $(P=0.009)$. Glucose concentration in the quinagolide-treated cows was greater than that in the $\mathrm{DH}$ and control cows before and after drying off $(P<0.001)$.

Feed restriction induced a sharp increase in plasma NEFA concentration, which was greater than that of QN and control cows $(P<0.001$; Figure 5B). After drying off, a treatment $\times$ time interaction $(P=0.005)$ was present. On d 1, plasma NEFA concentration in 
the control cows was greater than that in the $\mathrm{QN}$ and DH cows $(P=0.004$ and $P=0.026$, respectively $)$.

A treatment $\times$ time interaction $(P<0.01$; Figure $5 \mathrm{C}$ ) was observed for plasma BHBA concentration during both the pre-and post-drying off treatment periods. At the beginning of the treatment period, BHBA concentration was transiently greater in the blood of the
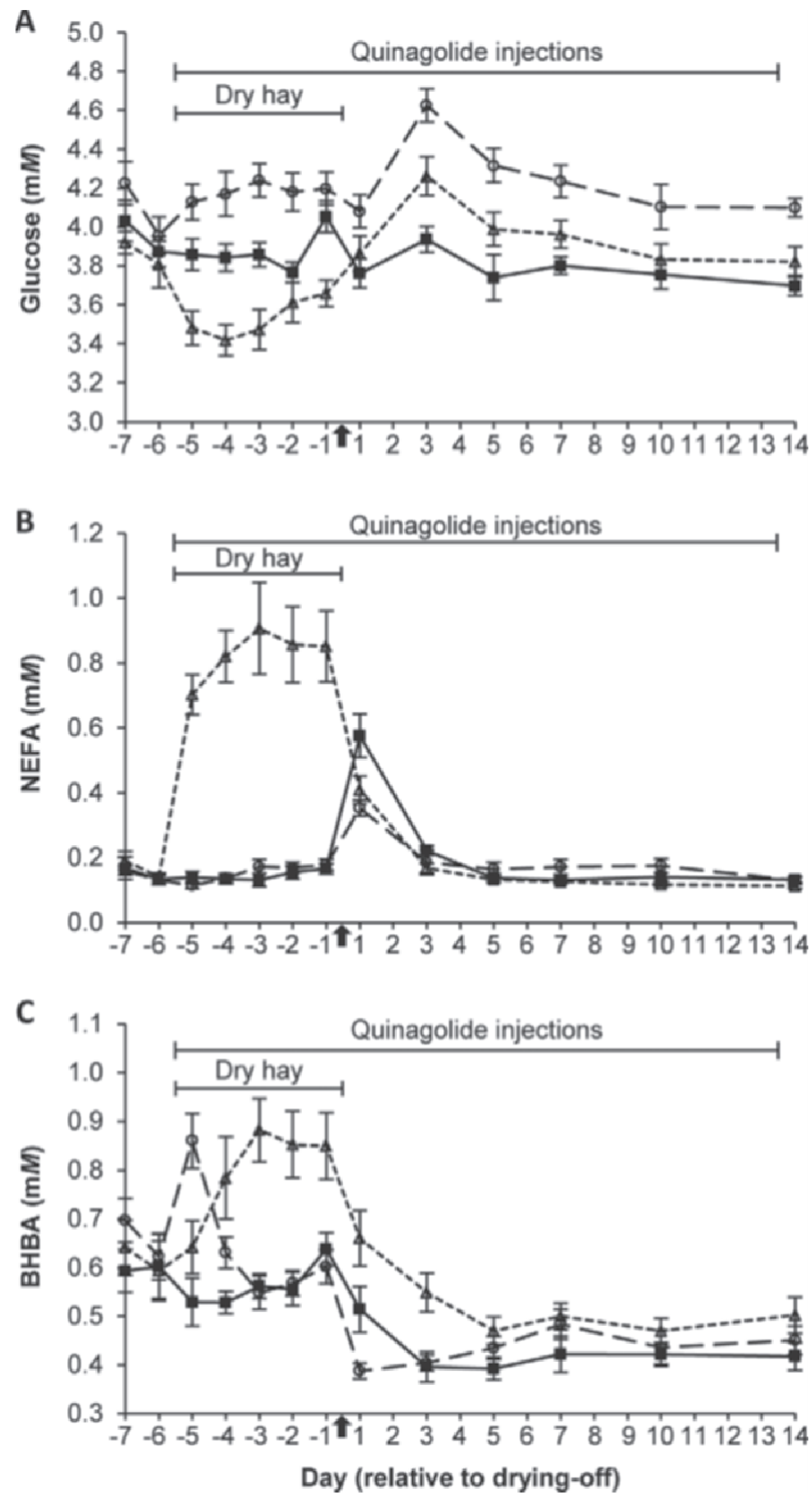

Figure 5. Blood concentrations of glucose (A), NEFA (B), and BHBA (C) in cows injected twice daily with $4 \mathrm{mg}$ of quinagolide from 5 d before drying off until $13 \mathrm{~d}$ after $(\mathrm{O}$, long-dashed line; $\mathrm{n}=8)$, cows fed only dry hay for the last $5 \mathrm{~d}$ before drying off $(\Delta$, short-dashed line; $\mathrm{n}=8)$, and control cows $(\boldsymbol{\square}$, solid line; $\mathrm{n}=8)$. Drying off is indicated by an arrow. Data are presented as LSM \pm SEM.
QN cows than in that of the DH and control cows $(P$ $=0.029$ and $P<0.001$, respectively, on $\mathrm{d}-5$ ). Plasma BHBA in the DH cows was greater than that in the QN and control cows from $\mathrm{d}-4$ to $-1(P<0.05)$. After drying off, plasma BHBA concentration in the $\mathrm{DH}$ cows remained greater than that in the QN cows on d 1 and $3(P<0.001$ and $P=0.003$, respectively $)$ and that in the control cows on $\mathrm{d} 1,3$, and $5(P=0.019, P$ $<0.001$, and $P=0.039$, respectively). Plasma BHBA concentration was greater in the control cows than in the $\mathrm{QN}$ cows on $\mathrm{d} 1(P=0.038)$, but was similar for both groups during the rest of the first 2 wk of the dry period.

The effects of feed restriction and quinagolide injections on plasma AA concentrations were assessed on $\mathrm{d}-6,-1$, and 2 (data not shown). The concentrations of only 3 AA (Asp, Glu, and Gln), among the 19 tested, were not affected by the treatments. The concentrations of $12 \mathrm{AA}$ were lower $(P<0.05)$ in the plasma of the DH cows in comparison with the $\mathrm{QN}$ and control cows, namely 9 AA (Ala, Asn, His, Lys, Pro, Ser, Thr, Trp, and Tyr) on $\mathrm{d}-1$ only and 3 AA (Ile, Leu, and Val) on both $\mathrm{d}-1$ and 2. Plasma Gly concentration was lower in the DH cows $(P=0.041)$ and QN cows $(P$ $=0.013)$ than in the control cows on d 2. Plasma Cys concentration was greater $(P=0.010)$ in the DH cows than in the control cows on $d-1$. The concentrations of Met and Phe remained similar for the $\mathrm{DH}$ and control cows on $\mathrm{d}-1$ and 2. Otherwise, quinagolide injections induced an increase $(P<0.05)$ in the concentrations of $4 \mathrm{AA}$ in comparison with the control cows, namely 2 AA (Met and Thr) on d -1 only and 2 AA (Phe and Tyr) on both $\mathrm{d}-1$ and 2 .

\section{PBMC Proliferation and Production of IL-4}

Peripheral blood mononuclear cells were incubated with serum harvested on $\mathrm{d}-6,-1$, and 2 to assess the effect of the treatments on PBMC proliferation (Figure $6 \mathrm{~A})$. The proliferation of concanavalin A-stimulated cells was similar for the 3 groups of animals on $\mathrm{d}-6$ and 2. On $\mathrm{d}-1$, the proliferation of PBMC incubated with serum from the DH cows was lower $(P=0.036)$ than that of PBMC incubated with serum from the QN and control cows. A negative correlation between PBMC proliferation and blood NEFA concentration was found on $\mathrm{d}-1(\mathrm{r}=-0.44, P=0.031)$. The production of IL-4 by stimulated PBMC in the cell culture supernatant collected after $24 \mathrm{~h}$ of incubation is presented in Figure 6B. Whereas IL-4 concentration was similar for the 3 groups on $\mathrm{d}-6$ and 2 , stimulated PBMC incubated with serum from the DH cows produced less IL-4 $(P<0.001)$ than did stimulated PBMC incubated with serum from the QN and control cows on $\mathrm{d}-1$. The con- 
centration of IL- 4 was correlated positively with PBMC proliferation $(\mathrm{r}=0.41, P=0.047)$ and negatively with plasma NEFA concentration $(\mathrm{r}=-0.44, P=0.030)$ on $\mathrm{d}-1$. None of the other metabolic markers were consistently correlated with $\mathrm{PBMC}$ proliferation and IL-4 concentration.

\section{DISCUSSION}

Quinagolide is a pharmaceutical compound that is used in humans for treating hyperprolactinemia and that binds specifically to the lactotroph dopamine D2 receptor, decreasing the synthesis and release of PRL (Brownell, 1996). As in our previous study (Ollier et al., 2013), quinagolide injections in the present experiment reduced milk and basal serum PRL concentration before and after drying off, as well as the amount of PRL released in the blood during milking. Quinagolide also caused a rapid reduction in milk production, as previously shown in cows in mid- (Lacasse et al., 2011) and late lactation (Ollier et al., 2013). Although it decreased DMI, quinagolide did not affect blood metabolite concentrations, indicating that the QN cows were not in negative energy balance. Moreover, after only 2 injections, quinagolide induced a $36 \%$ decrease in milk production, whereas only a $9 \%$ decrease in the DMI of the QN cows was observed. Therefore, the reduction in feed intake during the treatment period in quinagolide-treated cows probably plays a minor role in the reduction of milk production. These results support our previous conclusion (Lacasse et al., 2012) that quinagolide inhibits milk production mainly by its action on PRL secretion.

Feed restriction also inhibited basal serum PRL concentration and PRL secretion in milk. Vicini et al. (1988) reported that $21 \mathrm{~d}$ of feed restriction decreased serum PRL by more than $50 \%$. Similarly, Kuhla et al. (2010) showed that $60 \mathrm{~h}$ of severe feed restriction decreased blood PRL concentration by more than $80 \%$. Given that decreased milk yield was also observed in those studies and the present study, it raises the question as to whether the reduction of PRL secretion plays a role in the inhibition of milk production.

After drying off, the regression of mammary secretory tissue is accompanied by major changes in secretion composition that occur gradually during early involution (Oliver and Sordillo, 1989). In particular, these changes reflect the decrease in the secretory activity of mammary epithelial cells and the increase in the transfer of blood-derived factors. In the present experiment, several these indicators were used to monitor involution. An increase in the permeability of epithelial cell tight junctions, allowing paracellular transport between the interstitial space and milk, is
A

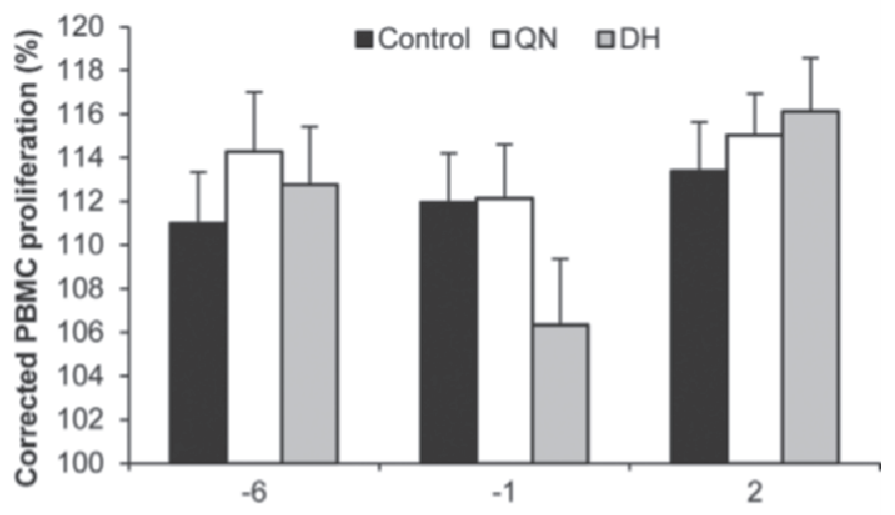

B

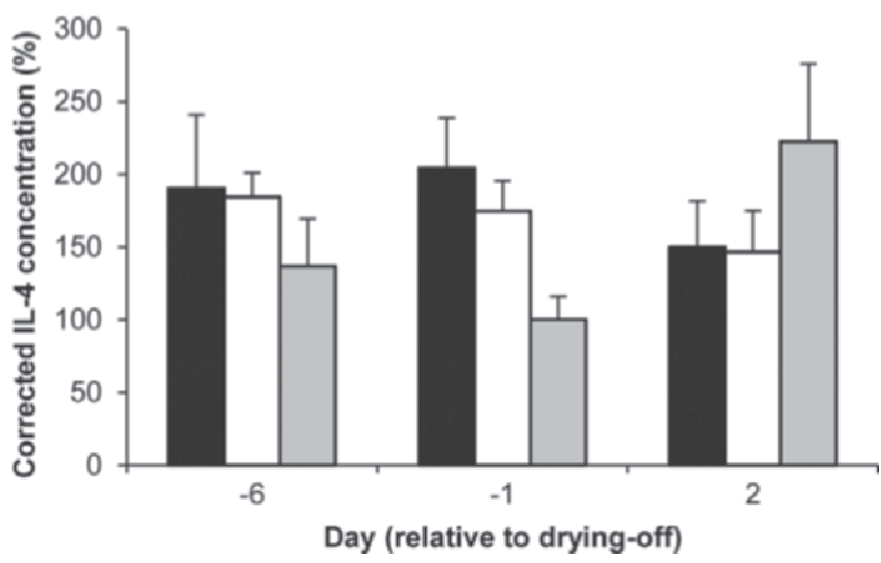

Figure 6. Percentage of proliferation (A) of concanavalin A-stimulated peripheral blood mononuclear cells (PBMC) incubated for $3.5 \mathrm{~d}$ with $5 \%$ serum sampled on $\mathrm{d}-6,-1$, or 2 from cows injected twice daily with $4 \mathrm{mg}$ of quinagolide from $5 \mathrm{~d}$ before drying off until $13 \mathrm{~d}$ after $(\mathrm{QN} ; \mathrm{n}=8)$, cows fed only dry hay for the last $5 \mathrm{~d}$ before drying off ( $\mathrm{DH} ; \mathrm{n}=8)$, and control cows $(\mathrm{n}=8)$; as well as concentrations of IL-4 (B) in the cell culture supernatant collected after $24 \mathrm{~h}$ of incubation. Data were corrected using the results obtained from a control-positive serum included in each assay and are presented as $\mathrm{LSM} \pm \mathrm{SEM}$. Incubation of PBMC with $\mathrm{d}-1$ serum of $\mathrm{DH}$ cows reduced proliferation $(P<0.05)$ and IL-4 secretion $(P<0.001)$.

characteristic of mammary gland involution (Nguyen and Neville, 1998). Both BSA concentration and $\mathrm{Na}^{+}-$ to- $\mathrm{K}^{+}$ratio increased faster in the mammary secretions of the QN and DH cows than in that of control cows, suggesting a hastening of tight junction disruption. Citrate-to-lactoferrin ratio, which has been reported to be a marker of the degree of mammary gland involution (Oliver and Smith, 1982), decreased faster in the secretions of the QN and DH cows. Similarly, the activity of MMP-2 increased faster in the milk of the QN and DH cows. This enzyme is able to degrade the basal membrane and is likely involved in tissue remodeling. The activity of this enzyme increases during involution in rodents (Talhouk et al., 1992) and during gradual involution in cows (Miller et al., 2006). According to 
these markers, it is clear that both nutritional restriction and the inhibition of PRL release accelerated the involution process. Furthermore, these markers started to change before drying off, suggesting that the involution process was already initiated at this stage.

Although explicit evidence of a direct relationship between milk production level and the rate of involution is lacking, it is reasonable to assume that such a relationship exists. Indeed, treatments that lower milk production at drying off, such as feed restriction, intermittent milking, or estrogen administration, are associated most of the time with faster involution (Bushe and Oliver, 1987; Athie et al., 1996). Even though the DH cows were producing less milk than the QN cows were at drying off, the rate of involution was similar for both groups. Previous reports suggested that PRL is required to maintain mammary epithelial integrity (Cowie et al., 1969; Linzell et al., 1975; Flint and Gardner, 1994). Therefore, PRL inhibition may have affected the rate of involution by both reducing milk production and disrupting epithelial integrity.

Most blood metabolites were unaffected by quinagolide injections, indicating that this treatment did not cause metabolic stress. In contrast, glucose concentration was greater in the quinagolide-treated cows. This effect was not observed previously in midlactation cows, possibly because the dose of quinagolide used and the effect on milk production were much lower than those in the present experiment (Lacasse et al., 2011). Oncedaily milking reduces milk output and, consequently, the amount of glucose used for lactose synthesis. In early lactation, this glucose-sparing effect translates into improved glycemia in cows milked once daily in comparison with cows milked more frequently, but this effect disappears as the energy balance become positive in all cows (Patton et al., 2006). In goats, PRL inhibition using bromocriptine increased glycemia without reducing milk production (Singh and Ludri, 1999), suggesting that the reduction in milk production is unlikely to be the cause of the increased glycemia in the QN cows. Accordingly, the effect on glucose was maintained after drying off in the present experiment. Given that higher PRL levels are associated with higher insulin sensitivity and lower blood glucose in healthy adult humans (Wagner et al., 2014), it is possible that the lower PRL concentration caused the increase in glucose concentration in the QN cows.

Unlike quinagolide treatment, feeding only dry hay before drying off caused significant metabolic stress. Blood NEFA and BHBA concentrations were increased, whereas glucose concentration was decreased, indicating that the DH cows were in negative energy balance (Chilliard et al., 1998). In addition, the concentrations of most AA were decreased, suggesting that protein metabolism was also disturbed. Similarly, Odensten et al. (2005) reported a markedly increased blood NEFA concentration and a moderately increased blood BHBA concentration in cows fed straw at drying off. Moreover, those researchers reported that blood cortisol was increased in cows fed straw, supporting the view that these animals are under stress. Metabolic stress during negative energy balance has been shown to cause immunosuppression (Carbonneau et al., 2012; Ster et al., 2012; Zarrin et al., 2014). The incubation of PBMC in serum harvested from the cows fed hay reduced the cells' ability to multiply and secrete IL-4. Similarly, previous studies found that PBMC proliferation and IL-4 secretion decreased in response to incubation with early postpartum sera (Carbonneau et al., 2012; Ster et al., 2012). In those experiments, negative correlations were found between serum NEFA concentrations and PBMC proliferation and IL-4 secretion. Accordingly, Ster et al. (2012) observed that serum harvested at 61 DIM but supplemented with enough NEFA to reach the level present in serum harvested at 5 DIM resulted in PBMC proliferation similar to that obtained with the latter serum. In addition, Lacetera et al. (2002) showed that NEFA concentrations greater than $250 \mu M$ inhibited concanavalin A-induced proliferation of ovine PBMC. Ster et al., (2012) and Franklin et al. (1991) reported a moderate negative effect of BHBA and acetoacetate on PBMC proliferation. However, the negative effect of BHBA was observed at a concentration greater than 1 $\mathrm{m} M$. As serum composed only $5 \%$ of the test medium, in order to reach an equivalent concentration of BHBA in the test medium, a serum sample would have to contain the supraphysiologic concentration of $20 \mathrm{mM}$ of BHBA. Concentrations of leucine below $0.4 \mathrm{~m} M$ have been shown to limit lymphocyte proliferation in vitro (Nonnecke et al., 1991). However, the culture medium used in the present study, RPMI 1640, contains $0.38 \mathrm{mM}$ of leucine and, therefore, was likely to supply enough leucine to fulfill lymphocyte requirements. In the present study, PBMC proliferation and IL-4 secretion were negatively correlated with NEFA concentrations but not with BHBA and leucine, suggesting that the negative effect of serum harvested from feed-restricted cows is also linked to their NEFA concentration.

The SCC in mammary secretions tended to increase faster in the quinagolide-treated cows than in the control cows. Evidence exists that immune cells play an important role in mammary gland involution, in particular to clear apoptotic cells and residual milk components (Atabai et al., 2007). Nevertheless, neutrophils and macrophages make up a high proportion of milk somatic cells and are important components of the mammary gland's first line of defense against bacterial colonization. It is therefore reasonable to assume 
that a high number of these cells may also help prevent colonization of the mammary gland.

In conclusion, both feed restriction and PRL-release inhibition decreased milk production before drying off and hastened mammary gland involution. However, the nutritional restriction strategy disturbed the metabolism and serum from these cows' impaired PBMC functions, whereas quinagolide treatment did not. Therefore, PRL release inhibition could be a new alternative for reducing milk production before drying off and for hastening mammary gland involution without disturbing the metabolism of the cow. Nevertheless, further research is required to determine whether these drying off procedures have an effect on the incidence of new IMI at drying off.

\section{ACKNOWLEDGMENTS}

The authors thank the following people (all from Agriculture and Agri-Food Canada, Sherbrooke, QC, Canada): Lisette St-James, Philippe Bernier-Dodier, Marie-Eve Gaillardetz, Caroline Roy, Véronique Roy, Jocelyne Renaud, Nohra Djellal, Martin Beaumont, Dominique Poulin, and Guillaume Salaün for providing technical assistance; as well as the dairy barn staff for taking care of the cows. The authors are grateful to Mary Varcoe, from the Translation Bureau, Public Works and Government Services Canada (Toronto, ON, Canada), for her careful editing of this manuscript. The authors also thank the National Hormone and Peptide Program and A. F. Parlow (Harbor-UCLA Medical Center, Torrance, CA) for providing the bovine PRL and antibodies. This research was financially supported by the Canadian Bovine Mastitis Research Network (St-Hyacinthe, QC, Canada) and Action Concertée Novalait-Fonds Québécois de Recherche sur la Nature et les Technologies- Ministère de l'Agriculture, des Pêcheries et de l'Alimentation du Québec-Agriculture et Agroalimentaire Canada (Québec, QC, Canada).

\section{REFERENCES}

Atabai, K., D. Sheppard, and Z. Werb. 2007. Roles of the innate immune system in mammary gland remodeling during involution. J. Mammary Gland Biol. Neoplasia 12:37-45.

Athie, F., K. C. Bachman, H. H. Head, M. J. Hayen, and C. J. Wilcox. 1996. Estrogen administered at final milk removal accelerates involution of bovine mammary gland. J. Dairy Sci. 79:220-226.

Bernier-Dodier, P., C. L. Girard, B. G. Talbot, and P. Lacasse. 2011. Effect of dry period management on mammary gland function and its endocrine regulation in dairy cows. J. Dairy Sci. 94:4922-4936.

Breau, W. C., and S. P. Oliver. 1986. Growth inhibition of environmental mastitis pathogens during physiologic transitions of the bovine mammary gland. Am. J. Vet. Res. 47:218-222.

Brownell, J. 1996. Quinagolide (Norprolac): A novel non-ergot prolactin inhibitor. Drugs Today (Barc) 32(Suppl. B):1-31.

Bushe, T., and S. P. Oliver. 1987. Natural protective factors in bovine mammary secretions following different methods of milk cessation. J. Dairy Sci. 70:696-704.
Calder, A. G., K. E. Garden, S. E. Anderson, and G. E. Lobley. 1999. Quantitation of blood and plasma amino acids using isotope dilution electron impact gas chromatography/mass spectrometry with $\mathrm{U}_{-}{ }^{13} \mathrm{C}$ amino acids as internal standards. Rapid Commun. Mass Spectrom. 13:2080-2083.

Canadian Council on Animal Care. 1993. Guide to the Care and Use of Experimental Animals. Vol. 1. 2nd ed. E. D. Olfert, B. M. Cross, and A. A. McWilliam, ed. CCAC, Ottawa, ON, Canada.

Carbonneau, E., A. M. de Passillé, J. Rushen, B. G. Talbot, and P. Lacasse. 2012. The effect of incomplete milking or nursing on milk production, blood metabolites, and immune functions of dairy cows. J. Dairy Sci. 95:6503-6512.

Chilliard, Y., F. Bocquier, and M. Doreau. 1998. Digestive and metabolic adaptations of ruminants to undernutrition, and consequences on reproduction. Reprod. Nutr. Dev. 38:131-152.

Cowie, A. T., P. E. Hartmann, and A. Turvey. 1969. The maintenance of lactation in the rabbit after hypophysectomy. J. Endocrinol. 43:651-662.

Doepel, L., and H. Lapierre. 2010. Changes in production and mammary metabolism of dairy cows in response to essential and nonessential amino acid infusions. J. Dairy Sci. 93:3264-3274.

Eberhart, R. J. 1986. Management of dry cows to reduce mastitis. J. Dairy Sci. 69:1721-1732.

Flint, D. J., and M. Gardner. 1994. Evidence that growth hormone stimulates milk synthesis by direct action on the mammary gland and that prolactin exerts effects on milk secretion by maintenance of mammary deoxyribonucleic acid content and tight junction status. Endocrinology 135:1119-1124.

Franklin, S. T., J. W. Young, and B. J. Nonnecke. 1991. Effects of ketones, acetate, butyrate, and glucose on bovine lymphocyte proliferation. J. Dairy Sci. 74:2507-2514.

Kehrli, M. E., Jr., B. J. Nonnecke, and J. A. Roth. 1989a. Alterations in bovine lymphocyte function during the periparturient period. Am. J. Vet. Res. 50:215-220.

Kehrli, M. E., Jr., B. J. Nonnecke, and J. A. Roth. 1989b. Alterations in bovine neutrophil function during the periparturient period. Am. J. Vet. Res. 50:207-214.

Kuhla, B., D. Albrecht, R. Bruckmaier, T. Viergutz, G. Nürnberg, and C. C. Metges. 2010. Proteome and radioimmunoassay analyses of pituitary hormones and proteins in response to feed restriction of dairy cows. Proteomics 10:4491-4500.

Lacasse, P., V. Lollivier, R. M. Bruckmaier, Y. R. Boisclair, G. F. Wagner, and M. Boutinaud. 2011. Effect of the prolactin-release inhibitor quinagolide on lactating dairy cows. J. Dairy Sci. 94:1302-1309.

Lacasse, P., V. Lollivier, F. Dessauge, R. M. Bruckmaier, S. Ollier, and M. Boutinaud. 2012. New developments on the galactopoietic role of prolactin in dairy ruminants. Domest. Anim. Endocrinol. 43:154-160.

Lacetera, N., O. Franci, D. Scalia, U. Bernabucci, B. Ronchi, and A. Nardone. 2002. Effects of nonesterified fatty acids and $\beta$-hydroxybutyrate on functions of mononuclear cells obtained from ewes. Am. J. Vet. Res. 63:414-418.

Linzell, J. L., M. Peaker, and J. C. Taylor. 1975. The effects of prolactin and oxytocin on milk secretion and on the permeability of the mammary epithelium in the rabbit. J. Physiol. 253:547-563.

Loiselle, M. C., C. Ster, B. G. Talbot, X. Zhao, G. F. Wagner, Y. R. Boisclair, and P. Lacasse. 2009. Impact of postpartum milking frequency on the immune system and the blood metabolite concentration of dairy cows. J. Dairy Sci. 92:1900-1912.

Miller, N., L. Delbecchi, D. Petitclerc, G. F. Wagner, B. G. Talbot, and P. Lacasse. 2006. Effect of stage of lactation and parity on mammary gland cell renewal. J. Dairy Sci. 89:4669-4677.

Mollering, H. 1989. Citrate. Pages 2-12 in Methods of Enzymatic Analysis. Vol. VII. 3rd ed. H. U. Bergmeyer, ed. VCH Publishers (UK) Ltd., Cambridge, UK.

Moreira da Silva, F., C. Burvenich, A. M. Massart Leën, and L. Brossé. 1998. Assessment of blood neutrophil oxidative burst activity in dairy cows during the period of parturition. Anim. Sci. $67: 421-426$. 
Nguyen, D. A. D., and M. C. Neville. 1998. Tight junction regulation in the mammary gland. J. Mammary Gland Biol. Neoplasia $3: 233-246$

Nonnecke, B. J., S. T. Franklin, and S. L. Nissen. 1991. Leucine and its catabolites alter mitogen-stimulated DNA synthesis by bovine lymphocytes. J. Nutr. 121:1665-1672.

Odensten, M. O., Y. Chilliard, and K. Holtenius. 2005. Effects of two different feeding strategies during dry-off on metabolism in highyielding dairy cows. J. Dairy Sci. 88:2072-2082.

Oliver, S. P., and K. L. Smith. 1982. Bovine mammary involution following intramammary infusion on colchicine and endotoxin at drying off. J. Dairy Sci. 65:801-813.

Oliver, S. P., and L. M. Sordillo. 1989. Approaches to the manipulation of mammary involution. J. Dairy Sci. 72:1647-1664.

Ollier, S., X. Zhao, and P. Lacasse. 2013. Effect of prolactin-release inhibition on milk production and mammary gland involution at drying-off in cows. J. Dairy Sci. 96:335-343.

Patton, J., D. A. Kenny, J. F. Mee, F. P. O’Mara, D. C. Wathes, M Cook, and J. J. Murphy. 2006. Effect of milking frequency and diet on milk production, energy balance, and reproduction in dairy cows. J. Dairy Sci. 89:1478-1487.

Pryce, J. E., R. J. Esslemont, R. Thompson, R. F. Veerkamp, M. A. Kossaibati, and G. Simm. 1998. Estimation of genetic parameters using health, fertility and production data from a management recording system for dairy cattle. Anim. Sci. 66:577-584.

Rajala-Schultz, P. J., J. S. Hogan, and K. L. Smith. 2005. Short communication: Association between milk yield at dry-off and probability of intramammary infections at calving. J. Dairy Sci. 88:577-579.

Singh, M., and R. S. Ludri. 1999. Plasma prolactin, blood metabolites and yield and composition of milk during early lactation in goats following administration of bromocryptine. Asian-australas. J. Anim. Sci. 12:585-589.

Snoek-van Beurden, P. A. M., and J. W. Von den Hoff. 2005. Zymographic techniques for the analysis of matrix metalloproteinases and their inhibitors. Biotechniques 38:73-83.

Ster, C., M. C. Loiselle, and P. Lacasse. 2012. Effect of postcalving serum nonesterified fatty acids concentration on the functionality of bovine immune cells. J. Dairy Sci. 95:708-717.

Talhouk, R. S., M. J. Bissell, and Z. Werb. 1992. Coordinated expression of extracellular matrix-degrading proteinases and their inhibitors regulates mammary epithelial function during involution. J. Cell Biol. 118:1271-1282.

Tremblay, G., P. Bernier-Dodier, L. Delbecchi, G. F. Wagner, B. G. Talbot, and P. Lacasse. 2009. Local control of mammary involution: Is stanniocalcin-1 involved? J. Dairy Sci. 92:1998-2006.

Trinder, P. 1969. Determination of glucose in blood using glucose oxidase with an alternative oxygen acceptor. Ann. Clin. Biochem. $6: 24-27$.

Vicini, J. L., W. S. Cohick, J. H. Clark, S. N. McCutcheon, and D. E. Bauman. 1988. Effects of feed intake and sodium bicarbonate on milk production and concentrations of hormones and metabolites in plasma of cows. J. Dairy Sci. 71:1232-1238.

Wagner, R., M. Heni, K. Linder, C. Ketterer, A. Peter, A. Böhm, E. Hatziagelaki, N. Stefan, H. Staiger, H. U. Häring, and A. Fritsche. 2014. Age-dependent association of serum prolactin with glycaemia and insulin sensitivity in humans. Acta Diabetol. 51:71-78. http://dx.doi.org/10.1007/s00592-013-0493-7.

Zarrin, M., O. Wellnitz, H. A. van Dorland, and R. M. Bruckmaier. 2014. Induced hyperketonemia affects the mammary immune response during lipopolysaccharide challenge in dairy cows. J. Dairy Sci. 97:330-339. 